\title{
Gambaran Emosi dan Tingkat Kecemasan pada Pasien Hipertensi di Puskesmas Bahu
}

\author{
${ }^{1}$ Richard K. Kati \\ ${ }^{2}$ Hendri Opod \\ ${ }^{2}$ Cicilia Pali
}

\author{
${ }^{1}$ Program Studi Pendidikan Dokter Fakultas Kedokteran Universitas Sam Ratulangi Manado \\ ${ }^{2}$ Bagian Psikologi Fakultas Kedokteran Universitas Sam Ratulangi Manado \\ Email: richard_kati@yahoo.com
}

\begin{abstract}
Anxiety and poor emotional management may trigger the occurence of hypertension. In reverse, hypertension is able to cause uncontrolled anxiety and emotion. This study was aimed to determine the emotional and anxiety level of patients with hypertension at Puskesmas Bahu (Primary Heath Center). This was a descriptive study with a cross-sectional design. Hamilton Anxiety Rating Scale was used to measure the anxiety level, and Positive Affect-Negative Affect Schedule was used to determine the emotion overview of hypertensive patients. Subjects of this study were all hypertensive patients who came to Pukesmas Bahu during the period of October to November 2017. There were 78 patients as respondents involved in this study; $49(62.8 \%)$ females and 29 (37.2\%) males. The results showed that 4 $(5.1 \%)$ respondents had dominant negative affect, while the other $74(94.9 \%)$ respondents had dominant positive affect. Dealing with the anxiety level, there were $23(29.5 \%)$ respondents with mild anxiety level, 21 (26.9\%) respondents with severe anxiety level, 20 (25.6\%) respondents with moderate anxiety level, $10(12.8 \%)$ respondents had no anxiety, and the other $4(5.1 \%)$ respondents had very severe anxiety. Conclusion: Most hypertensive patients at Puskesmas Bahu had dominant positive affect frequently associated with mild anxiety.
\end{abstract}

Keywords: emotion, anxiety, affect, hypertension

\begin{abstract}
Abstrak: Kecemasan dan manajemen emosi yang buruk dapat mencetuskan terjadinya hipertensi. Hipertensi juga dapat menyebabkan kecemasan dan emosi menjadi tidak terkendali. Penelitian ini bertujuan untuk mengetahui gambaran emosi dan tingkat kecemasan pada pasien hipertensi di Puskesmas Bahu. Jenis penelitian ialah deskriptif dengan desain potong lintang. Hamilton Anxiety Rating Scale digunakan untuk mengukur tingkat kecemasan dan Positive Affect Negative Affect Schedule digunakan untuk mengetahui gambaran emosi pasien hipertensi. Subyek penelitian ialah seluruh pasien hipertensi yang datang berkunjung ke Puskesmas Bahu pada periode Oktober sampai November 2017. Terdapat 78 responden dalam penelitian ini terdiri dari 49 orang $(62,8 \%)$ perempuan dan 29 orang $(37,2 \%)$ laki-laki. Gambaran emosi yang didapatkan ialah sebanyak 4 responden $(5,1 \%)$ memiliki afek negatif yang dominan sedangkan 74 responden $(94,9 \%)$ memiliki afek positif yang dominan. Gambaran tingkat kecemasan yang didapatkan ialah kecemasan ringan sebanyak 23 orang $(29,5 \%)$, kecemasan berat 21 orang $(26,9 \%)$, kecemasan sedang 20 orang $(25,6 \%)$, tidak ada kecemasan sebanyak 10 orang $(12,8 \%)$, dan kecemasan berat sekali sebanyak 4 orang $(5,1 \%)$. Simpulan: Sebagian besar pasien dengan hipertensi di Puskesmas Bahu memiliki afek positif yang dominan dan tersering disertai kecemasan ringan.
\end{abstract}

Kata kunci: emosi, kecemasan, afek, hipertensi 
Penyakit tidak menular akhir-akhir ini menjadi trend dalam masalah kesehatan di Indonesia. Selama dua dekade terakhir ini, telah terjadi transisi epidemiologis yang nyata yaitu penyakit tidak menular telah menjadi beban utama, meskipun beban penyakit menular masih berat juga. Indonesia sedang mengalami double burden penyakit, yaitu penyakit tidak menular dan penyakit menular sekaligus. Penyakit tidak menular utama meliputi hipertensi, diabetes melitus, kanker, dan penyakit paru obstruktif kronik (PPOK). ${ }^{1}$

Salah satu faktor penting sebagai pemicu penyakit tidak menular (PTM) atau non-communicable diseases (NCD) seperti penyakit jantung, stroke, dan lain-lain ialah hipertensi. Hipertensi saat ini menjadi penyebab kematian nomor wahid di dunia. ${ }^{2}$

Secara global, sekitar $20 \%$ dari populasi orang dewasa menyandang hipertensi. ${ }^{3}$ Indonesia sendiri di tahun 2013 dengan menggunakan unit analisis individu menunjukkan bahwa secara nasional 25,8\% penduduk Indonesia penyandang penyakit hipertensi. ${ }^{4}$

Berdasarkan data dari Dinas Kesehatan Kota Manado, hipertensi sendiri tiga tahun terakhir selalu berada pada posisi ke-2 penyakit yang paling menonjol di Manado. ${ }^{5}$ Berdasarkan survei awal yang dilakukan, pasien hipertensi di Puskesmas Bahu menempati urutan ketiga terbanyak di kota Manado setelah Puskesmas Ranotana Weru dan Puskesmas Kombos menurut data Dinas Kesehatan Kota Manado bulan April, Mei, dan Juni tahun 2017. Hipertensi sendiri menempati urutan kedua untuk penyakit yang paling banyak diderita pasien Puskesmas Bahu selama periode survei awal.

Puskesmas Bahu dipilih sebagai tempat penelitian karena puskesmas ini merupakan salah satu puskesmas dengan jumlah pasien hipertensi terbanyak di Manado. Diharapkan data yang didapat dari Puskesmas Bahu dapat menggambarkan emosi dan tingkat kecemasan pada pasien hipertensi di Kota Manado.

Hipertensi mempunyai hubungan yang erat dengan kecemasan. Teori ini telah dibuktikan oleh beberapa hasil penelitian sebelumnya. Penelitian tersebut mencari tahu hubungan antara disfungsi sistem saraf otonom, kecemasan, dan depresi pada pasien hipertensi yang belum diobati dan menyimpulkan bahwa kecemasan berperan penting dalam perkembangan hipertensi. ${ }^{6}$

Hipertensi juga memiliki hubungan erat dengan emosi. Beberapa penelitian telah dilakukan untuk membuktikan kebenaran teori tersebut. Pada penelitian tersebut ditelusuri perbedaan penurunan emosi pada pasien penyakit kardiovaskular dengan orang aleksitimia untuk lebih memahami peran dari disregulasi afek pada peningkatan tekanan darah. Hasil penelitian memperlihatkan penurunan ekspresi emosi berpotensi memengaruhi komunikasi interpersonal dan kesulitan psikososial; dengan demikian berkontribusi pada disregulasi dan peningkatan risiko penyakit kardiovaskular. $^{7}$

Atas dasar permasalahan tersebut maka peneliti tertarik untuk mengetahui gambaran pola emosi dan tingkat kecemasan pada pasien hipertensi dngan lokasi penelitian di Puskesmas Bahu.

\section{METODE PENELITIAN}

Jenis penelitian ini ialah deskriptif dengan desain potong lintang dengan menggunakan metode survei. Penelitian dilakukan di Puskesmas Bahu, Jalan Pulau Bunaken nomor 103, Bahu, Malalayang, Kota Manado, Sulawesi Utara sejak bulan Oktober 2017 sampai dengan November 2017.

Sasaran populasi dalam penelitian ini ialah pasien hipertensi yang datang memeriksakan diri di Puskesmas Bahu, Manado pada rentang waktu tersebut. Sampel pasien hipertensi dipilih dengan metode accidental sampling.

Data penelitian didapatkan melalui pengisian kuesioner oleh pasien. Kuesioner yang digunakan ialah Hamilton Anxiety Rating Scale untuk mengukur tingkat kecemasan dan Positive Affect Negative Affect Schedule untuk mengukur emosi. Data kemudian diolah secara deskriptif menggunakan SPSS. 
Kati, Opod, Pali: Gambaran emosi dan tingkat kecemasan ...

\section{HASIL PENELITIAN}

Penelitian ini dilakukan untuk mengetahui gambaran emosi dan tingkat kecemasan pada pasien hipertensi di Puskesmas Bahu. Responden penelitian yang memenuhi kriteria inklusi ialah sebanyak 78 pasien.

\section{Karakteristik responden}

Pada penelitian ini didapatkan responden dengan jenis kelamin perempuan berjumlah 49 orang $(62,8 \%)$ dan laki-laki sebanyak 29 orang $(37,2 \%)$.

Tabel 1 memperlihatkan rerata usia responden ialah 62,31 tahun dengan usia terbanyak ialah 64 tahun. Usia termuda responden ialah 40 tahun sedangkan yang tertua ialah 84 tahun. Kelompok usia 60-64 tahun yang terbanyak dengan jumlah 18 orang $(23,1 \%)$.

Tabel 1. Distribusi kelompok usia

\begin{tabular}{ccc}
\hline $\begin{array}{c}\text { Kelompok } \\
\text { usia }\end{array}$ & $\begin{array}{c}\text { Frekuensi } \\
\text { (n) }\end{array}$ & $\begin{array}{c}\text { Persentase } \\
(\%)\end{array}$ \\
\hline $40-44$ & 5 & 6,4 \\
$45-49$ & 4 & 5,1 \\
$50-54$ & 13 & 16,7 \\
$55-59$ & 7 & 9,0 \\
$60-64$ & 18 & 23,1 \\
$65-69$ & 10 & 12,8 \\
$70-74$ & 7 & 9,0 \\
$75-79$ & 10 & 12,8 \\
$80-84$ & 4 & 5,1 \\
Total & 78 & 100,0 \\
\hline
\end{tabular}

Tabel 2 memperlihatkan data pekerjaan responden yang sangat bervariasi. Ibu rumah tangga (IRT) merupakan pekerjaan yang terbanyak dengan jumlah 28 orang $(35,9 \%)$ dan kedua terbanyak ialah pensiunan berjumlah 26 orang (33,3\%).

Tabel 3 memperlihatkan bahwa 54 responden $(69,2 \%)$ dalam penelitian ini memiliki komplikasi dari hipertensi sedangkan 24 responden $(30,8 \%)$ lainnya tidak memiliki komplikasi.

Tabel 4 menjelaskan 51 responden $(81,0 \%)$ dengan sindrom metabolik, 8 orang $(12,7 \%)$ dengan penyakit jantung koroner (PJK), 3 orang $(4,8 \%)$ dengan gangguan ginjal kronis (GGK), dan 1 orang $(1,9 \%)$ dengan stroke.

Tabel 2. Distribusi pekerjaan responden

\begin{tabular}{ccc}
\hline Pekerjaan & $\begin{array}{c}\text { Frekuensi } \\
(\mathbf{n})\end{array}$ & $\begin{array}{c}\text { Persentase } \\
(\boldsymbol{\%})\end{array}$ \\
\hline Buruh & 1 & 1,3 \\
Dosen & 1 & 1,3 \\
IRT & 28 & 35,9 \\
Kader kesehatan & 1 & 1,3 \\
(Posyandu) & 4 & 5,1 \\
Karyawan swasta & 4 & 1,3 \\
Pendeta & 1 & 33,3 \\
Pensiunan & 26 & 2,6 \\
Petani & 2 & 2,6 \\
PNS & 2 & 1,3 \\
Sopir & 1 & 1,3 \\
Wartawan & 1 & 12,8 \\
Wiraswasta & 10 & 100,0 \\
Total & 78 & \\
\hline
\end{tabular}

Tabel 3. Distribusi komplikasi hipertensi

\begin{tabular}{ccc}
\hline Komplikasi & $\begin{array}{c}\text { Frekuensi } \\
(\mathbf{n})\end{array}$ & $\begin{array}{c}\text { Persentase } \\
(\mathbf{\%})\end{array}$ \\
\hline Komplikasi & 54 & 69,2 \\
Non-komplikasi & 24 & 30,8 \\
Total & 78 & 100,0 \\
\hline
\end{tabular}

Tabel 4. Distribusi jenis komplikasi

\begin{tabular}{ccc}
\hline Komplikasi & $\begin{array}{c}\text { Frekuensi } \\
(\mathbf{n})\end{array}$ & $\begin{array}{c}\text { Persentase } \\
(\boldsymbol{\%})\end{array}$ \\
\hline Sindrom & 51 & 81,0 \\
metabolik & 8 & 12,7 \\
PJK & 3 & 4,8 \\
GGK & 1 & 1,6 \\
Stroke & 63 & $100,1 \%$ \\
Total & & \\
\hline
\end{tabular}

\section{Gambaran emosi}

Tabel 5 menampilkan interpretasi skor seluruh responden. Terdapat sebanyak 4 responden $(5,1 \%)$ memiliki afek negatif yang dominan sedangkan 74 responden $(94,9 \%)$ lainnya memiliki afek positif sebagai afek dominan.

Tabel 6 menunjukkan dari 29 responden laki-laki, $3(10,3 \%)$ di antaranya memiliki afek negatif yang dominan sedangkan $26(89,7 \%)$ lainnya memiliki 
afek positif yang dominan. Pada perempuan hanya didapatkan 1 orang $(2,0 \%)$ memiliki afek negatif yang dominan sedangkan $48(98,0 \%)$ lainnya memiliki afek positif yang dominan. Terdapat 74 orang yang memiliki afek positif yang dominan; $48(64,9 \%)$ di antaranya ialah berjenis kelamin perempuan sedangkan 26 $(35,1 \%)$ orang lainnya ialah laki-laki.

Tabel 7 menunjukkan bahwa terdapat 74 orang yang memiliki afek positif dominan, dan kelompok usia 60-64 tahun menjadi yang terbanyak dengan jumlah 17 orang $(23,0 \%)$. Dengan demikian afek positif yang dominan menjadi yang paling banyak didapatkan di tiap kelompok usia.

Tabel 5. Distribusi jenis afek

\begin{tabular}{ccc}
\hline Emosi & $\begin{array}{c}\text { Frekuensi } \\
(\mathbf{n})\end{array}$ & $\begin{array}{c}\text { Persentase } \\
(\boldsymbol{\%})\end{array}$ \\
\hline Afek negatif & 4 & 5,1 \\
Afek positif & 74 & 94,9 \\
Total & 78 & 100,0 \\
\hline
\end{tabular}

Tabel 6. Tabulasi silang jenis kelamin dan emosi

\begin{tabular}{cccccc}
\hline & & & \multicolumn{2}{c}{ Interpretasi } & Total \\
& & & Afek negatif & Afek positif & \\
\hline \multirow{3}{*}{$\begin{array}{c}\text { Jenis } \\
\text { kelamin }\end{array}$} & \multirow{2}{*}{ Laki-laki } & Count & 3 & 26 & 29 \\
& & \% of total & 3,8 & 33,3 & 37,2 \\
& \multirow{2}{*}{ Perempuan } & Count & 1 & 48 & 49 \\
& & \% of total & 1,3 & 61,5 & 62,8 \\
& \multirow{2}{*}{ Total } & Count & 4 & 74 & 78 \\
& & \% of total & 5,1 & 94,9 & 100,0 \\
\hline
\end{tabular}

Tabel 7. Tabulasi silang kelompok usia dan emosi

\begin{tabular}{|c|c|c|c|c|c|}
\hline & & & Inter & etasi & Total \\
\hline & & & Afek negatif & Afek positif & \\
\hline & $40-44$ & Count & 0 & 5 & 5 \\
\hline & $40-44$ & $\%$ of Total & 0,0 & 6,4 & 6,4 \\
\hline & 1540 & Count & 0 & 4 & 4 \\
\hline & $4 J-49$ & $\%$ of Total & 0,0 & 5,1 & 5,1 \\
\hline & $50-54$ & Count & 0 & 13 & 13 \\
\hline & $30=54$ & $\%$ of Total & 0,0 & 16,7 & 16,7 \\
\hline & $55-59$ & Count & 2 & 5 & 7 \\
\hline & & $\%$ of Total & 2,6 & 6,4 & 9,0 \\
\hline Kelompok usia & $60-64$ & Count & 1 & 17 & 18 \\
\hline (tahun) & $00-04$ & $\%$ of Total & 1,3 & 21,8 & 23,1 \\
\hline & 6560 & Count & 0 & 10 & 10 \\
\hline & $0-09$ & $\%$ of Total & 0,0 & 12,8 & 12,8 \\
\hline & $70-74$ & Count & 1 & 6 & 7 \\
\hline & $10-14$ & $\%$ of Total & 1,3 & 7,7 & 9,0 \\
\hline & 75-79 & Count & 0 & 10 & 10 \\
\hline & & $\%$ of Total & 0,0 & 12,8 & 12,8 \\
\hline & $80-84$ & Count & 0 & 4 & 4 \\
\hline & & $\%$ of Total & 0,0 & 5,1 & 5,1 \\
\hline Total & & Count & 4 & 74 & 78 \\
\hline & & $\%$ of Total & 5,1 & 94,9 & 100,0 \\
\hline
\end{tabular}


Tabel 8 menunjukkan terdapat 74 orang yang memiliki afek positif yang dominan; IRT menjadi yang terbanyak dengan jumlah 27 orang $(36,4 \%)$. Dengan demikian afek positif yang dominan selalu terbanyak di tiap jenis pekerjaan kecuali pada petani di mana semuanya memiliki afek negatif yang dominan.

Tabel 8. Tabulasi silang pekerjaan dan emosi

\begin{tabular}{|c|c|c|c|c|c|}
\hline & & & \multicolumn{2}{|c|}{ Emosi } & \multirow[t]{2}{*}{ Total } \\
\hline & & & $\begin{array}{c}\text { Afek } \\
\text { positif }\end{array}$ & $\begin{array}{c}\text { Afek } \\
\text { negatif }\end{array}$ & \\
\hline \multirow{26}{*}{ Pekerjaan } & \multirow{2}{*}{ Buruh } & Count & 1 & 0 & 1 \\
\hline & & $\%$ of Total & $1,3 \%$ & $0,0 \%$ & $1,3 \%$ \\
\hline & \multirow{2}{*}{ Dosen } & Count & 1 & 0 & 1 \\
\hline & & $\%$ of Total & $1,3 \%$ & $0,0 \%$ & $1,3 \%$ \\
\hline & \multirow{2}{*}{ Ibu rumah tangga } & Count & 27 & 1 & 28 \\
\hline & & $\%$ of Total & $34,6 \%$ & $1,3 \%$ & $35,9 \%$ \\
\hline & \multirow{2}{*}{$\begin{array}{l}\text { Kader kesehatan } \\
\text { (Posyandu) }\end{array}$} & Count & 1 & 0 & 1 \\
\hline & & $\%$ of Total & $1,3 \%$ & $0,0 \%$ & $1,3 \%$ \\
\hline & \multirow{2}{*}{ Karyawan swasta } & Count & 3 & 1 & 4 \\
\hline & & $\%$ of Total & $3,8 \%$ & $1,3 \%$ & $5,1 \%$ \\
\hline & \multirow{2}{*}{ Pendeta } & Count & 1 & 0 & 1 \\
\hline & & $\%$ of Total & $1,3 \%$ & $0,0 \%$ & $1,3 \%$ \\
\hline & \multirow{2}{*}{ Pensiunan } & Count & 26 & 0 & 26 \\
\hline & & $\%$ of Total & $33,3 \%$ & $0,0 \%$ & $33,3 \%$ \\
\hline & \multirow{2}{*}{ Petani } & Count & 0 & 2 & 2 \\
\hline & & $\%$ of Total & $0,0 \%$ & $2,6 \%$ & $2,6 \%$ \\
\hline & \multirow{2}{*}{ PNS } & Count & 2 & 0 & 2 \\
\hline & & $\%$ of Total & $2,6 \%$ & $0,0 \%$ & $2,6 \%$ \\
\hline & \multirow{2}{*}{ Sopir } & Count & 1 & 0 & 1 \\
\hline & & $\%$ of Total & $1,3 \%$ & $0,0 \%$ & $1,3 \%$ \\
\hline & \multirow{2}{*}{ Wartawan } & Count & 1 & 0 & 1 \\
\hline & & $\%$ of Total & $1,3 \%$ & $0,0 \%$ & $1,3 \%$ \\
\hline & \multirow{2}{*}{ Wiraswasta } & Count & 10 & 0 & 10 \\
\hline & & $\%$ of Total & $12,8 \%$ & $0,0 \%$ & $12,8 \%$ \\
\hline & \multirow{2}{*}{ Total } & Count & 74 & 4 & 78 \\
\hline & & $\%$ of Total & $94,9 \%$ & $5,1 \%$ & $100,0 \%$ \\
\hline
\end{tabular}

Tabel 9 memaparkan dari 4 orang yang memiliki afek negatif yang dominan, 3 orang $(75,0 \%)$ memiliki komplikasi sedangkan 1 orang lainnya $(25,0 \%)$ tidak memiliki komplikasi. Hampir semua jenis komplikasi terdapat responden yang memiliki afek negatif yang dominan. Sindrom metabolik merupakan yang paling banyak dengan jumlah 3 orang $(75,0 \%)$. Terdapat 74 orang yang memiliki afek positif yang dominan; 51 orang $(68,9 \%)$ di antaranya memiliki komplikasi. Dengan demikian afek positif yang dominan terbanyak ditemukan di tiap jenis komplikasi. 
Tabel 9. Tabulasi silang komplikasi dan emosi

\begin{tabular}{|c|c|c|c|c|c|}
\hline & & & & & Total \\
\hline & & & $\begin{array}{c}\text { Afek } \\
\text { positif }\end{array}$ & $\begin{array}{c}\text { Afek } \\
\text { negatif }\end{array}$ & \\
\hline & Sindrom motoholik & Count & 48 & 3 & 51 \\
\hline & Sindrom metaboink & $\%$ of Total & $88,9 \%$ & $5,6 \%$ & $94,4 \%$ \\
\hline & PIK $>2+2>$ & Count & 7 & 1 & 8 \\
\hline Komnlikgai & 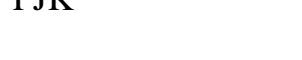 & $\%$ of Total & $13,0 \%$ & $1,9 \%$ & $14,8 \%$ \\
\hline Kompinkası & $C C V$ & Count & 2 & 1 & 3 \\
\hline & GUK & $\%$ of Total & $3,7 \%$ & $1,9 \%$ & $5,6 \%$ \\
\hline & Strole & Count & 1 & 0 & 1 \\
\hline & Stroke & $\%$ of Total & $1,9 \%$ & $0,0 \%$ & $1,9 \%$ \\
\hline & T. & Count & 51 & 3 & 54 \\
\hline & Iotal & $\%$ of Total & $94,4 \%$ & $5,6 \%$ & $100,0 \%$ \\
\hline
\end{tabular}

\section{Gambaran kecemasan}

Tabel 10 menjelaskan interpretasi dari skor yang didapat seluruh responden. Sebanyak 10 responden $(12,8 \%)$ tidak memiliki kecemasan, 23 responden $(29,5 \%)$ memiliki kecemasan ringan, 20 responden $(25,6 \%)$ memiliki kecemasan sedang, 21 responden $(26,9 \%)$ memiliki kecemasan berat, dan 4 responden $(5,1 \%)$ memiliki kecemasan berat sekali.

Tabel 10. Distribusi tingkat kecemasan

\begin{tabular}{ccc}
\hline $\begin{array}{c}\text { Tingkat } \\
\text { kecemasan }\end{array}$ & $\begin{array}{c}\text { Frekuensi } \\
(\mathbf{n})\end{array}$ & $\begin{array}{c}\text { Persentase } \\
(\boldsymbol{\%})\end{array}$ \\
\hline Tidak ada & 10 & 12,8 \\
Ringan & 23 & 29,5 \\
Sedang & 20 & 25,6 \\
Berat & 21 & 26,9 \\
Berat sekali & 4 & 5,1 \\
Total & 78 & 100,0 \\
\hline
\end{tabular}

Tabel 11 menggambarkan tabulasi silang antara jenis kelamin responden dengan tingkat kecemasan. Dari 29 lakilaki, kecemasan sedang yang paling banyak didapat dengan jumlah 10 orang $(34,5 \%)$. Pada 49 responden perempuan, kecemasan ringan menjadi yang paling banyak didapat dengan jumlah 16 orang (32,7\%). Dengan demikian perempuan dominan di hampir semua tingkat kecemasan.

Tabel 12 mendapatkan bahwa dari 10 orang yang tidak mengalami kecemasan, kelompok usia 60-64 tahun mendominasi dengan jumlah 3 orang (30,0\%). Pada 23 orang yang mengalami kecemasan ringan, kelompok usia 60-64 tahun mendominasi dengan jumlah 7 orang $(30,4 \%)$. Pada 20 orang yang mengalami kecemasan sedang, kelompok usia 60-64 tahun dan 65-69 tahun mendominasi dengan jumlah masingmasing 4 orang $(20,0 \%)$. Pada 21 orang yang mengalami kecemasan berat, kelompok usia 70-74 tahun mendominasi dengan jumlah 4 orang $(19,0 \%)$. Pada 4 orang yang mengalami kecemasan berat sekali, 2 orang $(50,0 \%)$ berasal dari kelompok usia 50-54 tahun, dan 2 orang $(50,0 \%)$ berasal dari kelompok usia 60-64 tahun.

Tabel 12 juga menjelaskan bahwa kecemasan ringan dominan ditemukan pada kelompok usia 50-54 tahun (46,2\%), 60-64 tahun $(38,9 \%)$, dan $80-84$ tahun $(50,0 \%)$. Kecemasan sedang dominan ditemukan pada kelompok usia 65-69 tahun (40,0\%). Kecemasan berat dominan ditemukan pada kelompok usia 55-59 tahun (42,9\%). Kecemasan sedang dan berat $(40,0 \%)$ pada kelompok usia 40-44 tahun. Kecemasan sedang dan berat $(40,0 \%)$ pada kelompok usia 45-49 tahun. Kecemasan ringan dan berat $(30,0 \%)$ pada kelompok usia 75-79 tahun. 
Kati, Opod, Pali: Gambaran emosi dan tingkat kecemasan ...

Tabel 11. Tabulasi silang jenis kelamin dan tingkat kecemasan

\begin{tabular}{ccccccccc}
\hline & & & \multicolumn{3}{c}{ Interpretasi kecemasan } & Total \\
& & Berat & $\begin{array}{c}\text { Berat } \\
\text { sekali }\end{array}$ & Ringan & Sedang & $\begin{array}{c}\text { Tidak } \\
\text { ada }\end{array}$ & \\
\hline \multirow{3}{*}{$\begin{array}{c}\text { Jenis } \\
\text { kelamin }\end{array}$} & \multirow{2}{*}{ Laki-laki } & Count & 8 & 0 & 7 & 0 & 4 & 9 \\
& & \% of Total & 10,3 & 0,0 & 9,0 & 12,8 & 5,1 & 37,2 \\
& \multirow{2}{*}{ Perempuan } & Count & 13 & 4 & 16 & 10 & 6 & 49 \\
& & \% of Total & 16,7 & 5,1 & 20,5 & 12,8 & 7,7 & 62,8 \\
& \multirow{2}{*}{ Total } & Count & 21 & 4 & 23 & 20 & 10 & 8 \\
& & \% of Total & 26,9 & 5,1 & 29,5 & 25,6 & 12,8 & 100,0 \\
\hline
\end{tabular}

Tabel 12. Tabulasi silang usia dan tingkat kecemasan

\begin{tabular}{|c|c|c|c|c|c|c|c|c|}
\hline & & & & & erpretasi & kecemasa & & Total \\
\hline & & & Berat & $\begin{array}{l}\text { Berat } \\
\text { sekali }\end{array}$ & Ringan & Sedang & $\begin{array}{c}\text { Tidak } \\
\text { ada }\end{array}$ & \\
\hline & & $\overline{\text { Count }}$ & 2 & 0 & 0 & 2 & 1 & 5 \\
\hline & $40-44$ & $\%$ of Total & 2,6 & 0,0 & 0,0 & 2,6 & 1,3 & 6,4 \\
\hline & 1540 & Count & 2 & 0 & 0 & 2 & 0 & 4 \\
\hline & $45-49$ & $\%$ of Total & 2,6 & 0,0 & 0,0 & 2,6 & 0,0 & 5,1 \\
\hline & 5054 & Count & 2 & 2 & 6 & 3 & 0 & 13 \\
\hline & $30-54$ & $\%$ of Total & 2,6 & 2,6 & 7,7 & 3,8 & 0,0 & 16,7 \\
\hline & 5550 & Count & 3 & 0 & 1 & 1 & 2 & 7 \\
\hline & $55-59$ & $\%$ of Total & 3,8 & 0,0 & 1,3 & 1,3 & 2,6 & 9,0 \\
\hline Kelompok usia & 6064 & Count & 2 & 2 & 7 & 4 & 3 & 18 \\
\hline (tahun) & 60-64 & $\%$ of Total & 2,6 & 2,6 & 9,0 & 5,1 & 3,8 & 23,1 \\
\hline & & Count & 3 & 0 & 2 & 4 & 1 & 10 \\
\hline & $65-69$ & $\%$ of Total & 3,8 & 0,0 & 2,6 & 5,1 & 1,3 & 12,8 \\
\hline & $70-74$ & Count & 4 & 0 & 2 & 1 & 0 & 7 \\
\hline & $10-14$ & $\%$ of Total & 5,1 & 0,0 & 2,6 & 1,3 & 0,0 & 9,0 \\
\hline & $75-79$ & Count & 3 & 0 & 3 & 2 & 2 & 10 \\
\hline & & $\%$ of Total & 3,8 & 0,0 & 3,8 & 2,6 & 2,6 & 12,8 \\
\hline & $80-84$ & Count & 0 & 0 & 2 & 1 & 1 & 4 \\
\hline & ov-04 & $\%$ of Total & 0,0 & 0,0 & 2,6 & 1,3 & 1,3 & 5,1 \\
\hline Total & & Count & 21 & 4 & 23 & 20 & 10 & 78 \\
\hline Total & & $\%$ of Total & 26,9 & 5,1 & 29,5 & 25,6 & 12,8 & 100,0 \\
\hline
\end{tabular}

Tabel 13 menjelaskan bahwa dari 10 orang yang tidak mengalami kecemasan, pensiunan mendominasi dengan jumlah 4 orang $(40,0 \%)$. Terdapat 23 orang yang mengalami kecemasan ringan, pensiunan mendominasi dengan jumlah 11 orang $(47,8 \%)$. Terdapat 20 orang yang mengalami kecemasan sedang, ibu rumah tangga mendominasi dengan jumlah 9 orang $(45,0 \%)$. Terdapat 21 orang yang mengalami kecemasan berat, ibu rumah tangga mendominasi dengan jumlah 8 orang $(38,1 \%)$. Terdapat 4 orang yang mengalami kecemasan berat sekali, 2 orang $(50,0 \%)$ berasal dari jenis pekerjaan ibu rumah tangga, dan 2 orang $(50,0 \%)$ berasal dari jenis pekerjaan wiraswasta. Tabel 13 juga menjelaskan bahwa tidak ada kecemasan dominan ditemukan pada wartawan $(100,0 \%)$. Kecemasan ringan dominan ditemukan pada dosen $(100,0 \%)$, karyawan swasta $(25,0 \%)$, pensiunan $(42,3 \%)$, dan sopir $(100,0 \%)$. Kecemasan sedang dominan ditemukan pada IRT $(32,1 \%)$ dan pendeta $(100,0 \%)$. Kecemasan berat dominan ditemukan pada buruh $(100,0 \%)$ 
dan kader kesehatan $(100,0 \%)$. Kecemasan sedang dan berat dominan ditemukan pada petani masing-masing $50,0 \%$ dan wiraswasta masing-masing 30,0\%. Kecemasan ringan dan berat pada PNS masing-masing $50,0 \%$.
Tabel 14 menjelaskan bahwa dari 10 orang yang tidak mengalami kecemasan, 6 orang $(60,0 \%)$ memiliki komplikasi dan 4 orang $(40,0 \%)$ tidak memiliki komplikasi. Sindrom metabolik mendominasi di semua tingkat kecemasan pada penelitian ini.

Tabel 13. Tabulasi silang pekerjaan dan tingkat kecemasan

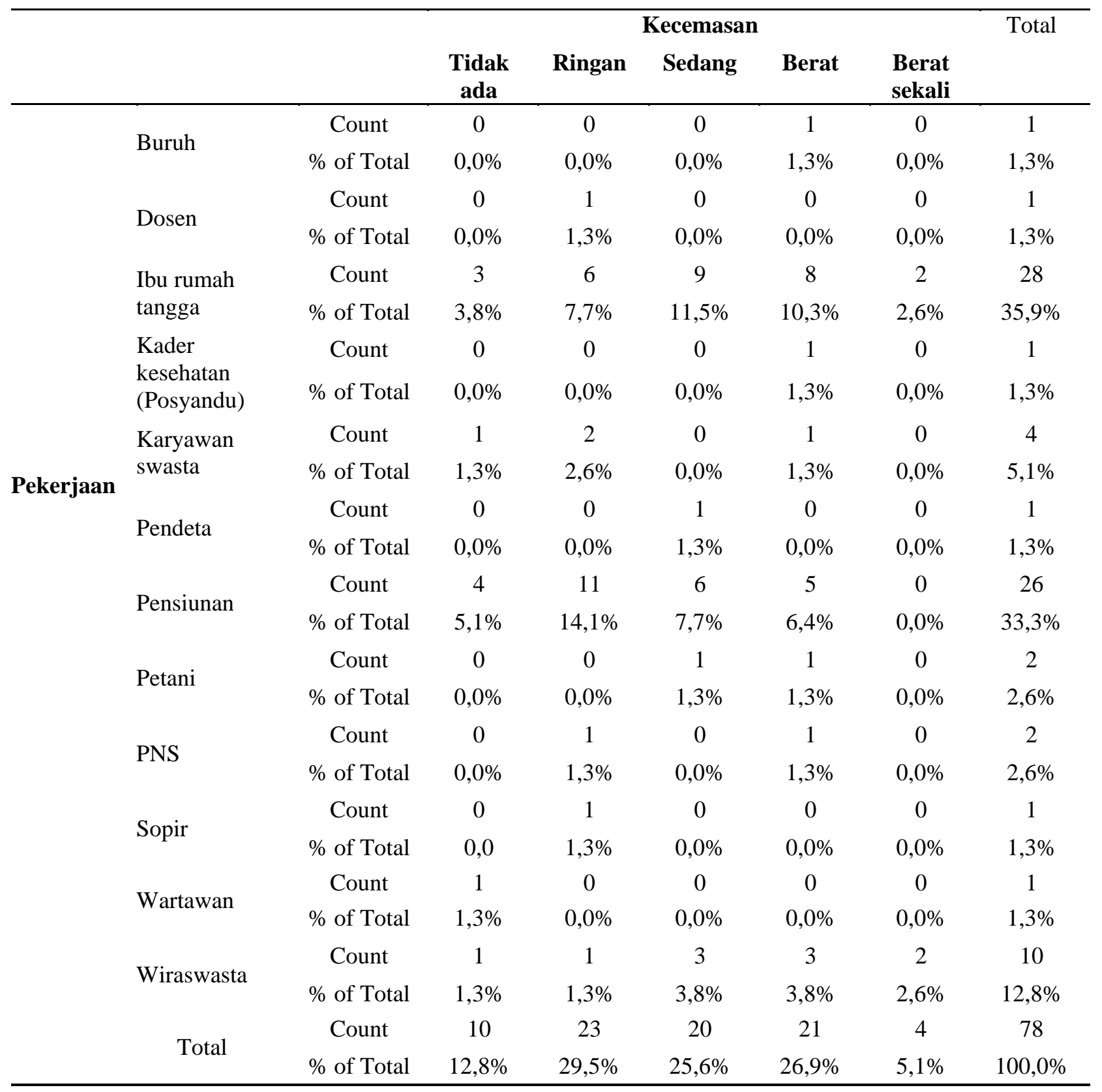

\section{BAHASAN}

Penelitian ini dilakukan di Puskesmas Bahu dari tanggal 24 Oktober 2017 sampai 18 November 2017. Pasien hipertensi yang memenuhi kriteria inklusi berjumlah 78 responden. Banyak responden yang tidak bersedia untuk mengisi sendiri kuesioner dengan beberapa alasan seperti tidak membawa kacamata baca dan buru-buru sehingga peneliti akhirnya mengambil keputusan untuk mewawancarai pasien yang datang satu per satu. 
Kati, Opod, Pali: Gambaran emosi dan tingkat kecemasan ...

Tabel 14. Tabulasi silang komplikasi dan tingkat kecemasan

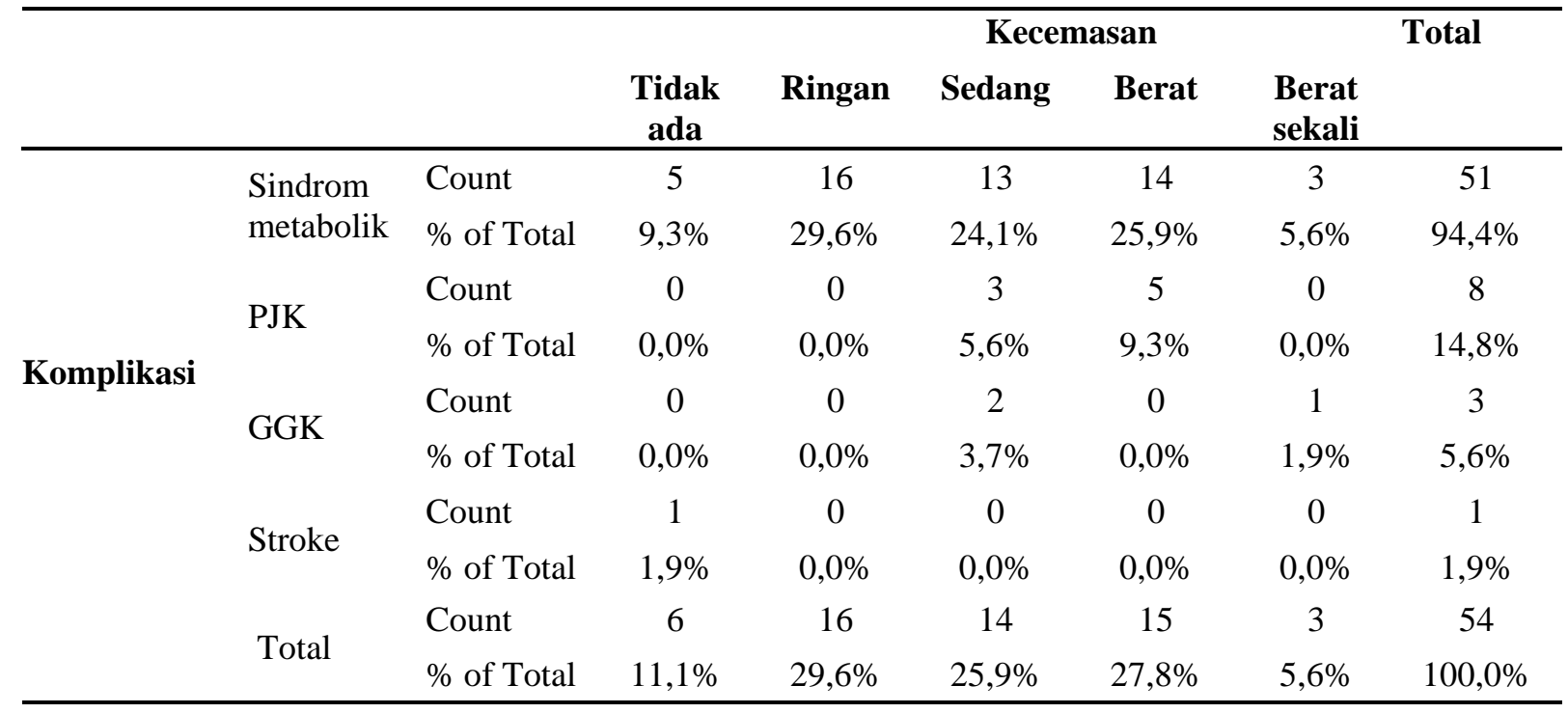

\section{Karakteristik responden}

Berdasarkan jenis kelamin, penelitian ini didapatkan dominan yaitu perempuan dengan jumlah 49 orang $(62,8 \%)$. Hal ini sesuai dengan penelitian oleh Novitaningtyas $^{8}$ yang mendapatkan pasien hipertensi didominasi oleh perempuan dengan jumlah 32 orang $(80 \%)$.

Berdasarkan usia, pada penelitian ini didapatkan terbanyak ialah pasien lansia menurut WHO (60-74 tahun) dengan jumlah 35 orang $(44,9 \%)$ dengan rerata usia 62,31 tahun. Hal ini serupa dengan penelitian oleh Novitaningtyas ${ }^{8}$ yang mendapatkan pasien hipertensi terbanyak ialah lansia (60-74 tahun) dengan jumlah 33 orang $(82,5 \%)$.

Berdasarkan pekerjaan, pada penelitian ini didapatkan yang terbanyak ialah pasien yang tidak bekerja (pensiunan dan ibu rumah tangga) dengan jumlah 54 orang $(69,2 \%)$ yang selaras dengan penelitian oleh Basofi $^{9}$ yang mendapatkan pasien terbanyak ialah yang tidak bekerja dengan jumlah 30 orang $(61,22 \%)$.

Jumlah data yang didapat sebanyak 78 pasien hipertensi didominasi oleh 54 orang $(69,2 \%)$ yang sudah memiliki komplikasi. Penelitian ini selaras dengan penelitian Prasetyorini dan Prawesti ${ }^{10}$ terhadap 29 responden yang mendapatkan 18 responden (62\%) mengalami komplikasi hipertensi dan 11 responden (38\%) tidak mengalami komplikasi hipertensi. Sindrom metabolik menjadi komplikasi yang dominan pada penelitian ini dengan jumlah 51 orang $(81 \%)$. Hal ini sejalan juga dengan penelitian oleh Andrea ${ }^{11}$ yang menyatakan bahwa hipertensi dapat mengakibatkan komplikasi seperti stroke, kelemahan jantung, PJK, gangguan ginjal, sindrom metabolik, dan lain-lain yang berakibat pada kelemahan fungsi dari organ vital seperti otak, ginjal dan jantung yang dapat berakibat kecacatan bahkan kematian.

\section{Gambaran emosi}

Telah dipahami bahwa umumnya perempuan lebih banyak menampilkan ketakutan dan kesedihan dibandingkan laki-laki yang lebih banyak menampilkan kemarahan. Perempuan juga lebih mudah dikenali emosinya dari ekspresi raut muka dan pengungkapan emosi yang sering terucap. Perempuan cenderung berekspresi apa adanya ketika berada dalam emosional yang tidak sesuai harapan dan anggapan mereka. Dalam budaya Asia, contohnya di Indonesia, laki-laki lebih dituntut untuk dapat mengendalikan emosi, tetap tenang dalam situasi emosional, dan lebih dapat menekan ekspresi emosinya sehingga tak tampil keluar sedang perempuan lebih bebas untuk mengekspresikan emosi dan 
lebih dikenal sebagai makhluk emosional dibandingkan laki-laki. Di budaya Barat, ekspresi emosi dileluasakan untuk ditampilkan baik oleh perempuan maupun lakilaki. ${ }^{12}$

Mengenai usia, Brener dan Salovey mengungkapkan beberapa faktor yang dapat memengaruhi regulasi emosi, salah satunya ialah usia. Semakin bertambahnya usia seseorang maka relatif semakin baik regulasi emosinya. ${ }^{12}$ Pada penelitian oleh Shallcross et al. ${ }^{13}$ didapatkan bahwa afek negatif seperti marah lebih rendah seiring bertambahnya usia tapi tidak dengan kesedihan. Hal ini dikarenakan pertambahan usia berkaitan dengan peningkatan penerimaan diri terhadap pengalaman yang berpotensi menimbulkan emosi negatif.

CareerCast.com ${ }^{14}$ menyatakan bahwa stres karena pekerjaan dapat berasal dari beberapa faktor seperti lingkungan pekerjaan yang berbahaya, berhadapan dengan banyak orang atau pelayanan publik, dan bayaran yang didapat. Ibu rumah tangga $(35,9 \%)$ dan pensiunan $(33,3 \%)$ yang merupakan dua pekerjaan terbanyak pada penelitian ini memiliki afek positif yang dominan. Ibu rumah tangga dan pensiunan tidak memiliki lingkungan pekerjaan yang berbahaya, tidak berhadapan dengan orang banyak atau pelayanan publik, dan tetap menerima pendapatan walaupun pada IRT pendapatan tidak didapat secara langsung melainkan dari suami atau pekerjaan lain.

Penelitian oleh Prasetyorini dan Prawesti ${ }^{10}$ tentang komplikasi hipertensi, emosi, dan kecemasan menyatakan bahwa banyak hal yang dapat menyebabkan komplikasi hipertensi, salah satunya ialah emosi. Ketika seseorang memiliki afek negatif dalam tubuh maka tubuh akan memroduksi hormon yang dapat meningkatkan tekanan darah, peningkatan tekanan darah inilah yang memicu terjadinya komplikasi hipertensi. Dampak terjadinya komplikasi hipertensi membuat kualitas hidup penderita menjadi rendah dan kemungkinan terburuknya ialah terjadinya kematian pada penderita akibat komplikasi hipertensi yang dimilikinya. Komplikasi ini kemudian dapat memengaruhi emosi itu sendiri dan menimbulkan kecemasan.

Hal tersebut tidak sesuai dengan yang didapatkan pada penelitian ini. Sebagian besar responden dengan komplikasi memiliki afek positif yang dominan. Mereka mengakui bahwa kadang merasa sedih dan kecewa namun mereka tidak ingin larut dalam emosi tersebut dan lebih memilih untuk selalu berpikiran positif. Mereka selalu berpikiran positif diakui karena mereka sering beribadah dan hal itu membuat mereka selalu merasa nyaman.

Penelitian ini menunjukkan bahwa kebanyakan pasien hipertensi di Puskesmas Bahu masih bisa mengelola emosi yang ada pada diri mereka. Pada saat pengambilan data, banyak yang mengaku bahwa hipertensi tidak menurunkan minat mereka sama sekali terhadap hobi bahkan beberapa mengaku minat terhadap hobi mereka bertambah setelah menderita hipertensi. Ada juga yang mengaku setelah didiagnosis hipertensi menjadi lebih sering beribadah, berkumpul bersama keluarga, lebih aktif, dan lebih banyak melakukan hal-hal yang positif. Namun di lain pihak, sebagian kecil memiliki afek negatif yang dominan selama menyandang hipertensi. Dengan demikian sebagian besar pasien hipertensi di Puskesmas Bahu sudah memiliki pengelolaan emosi yang baik dan paham benar bahwa emosi positif harus selalu ada dalam diri mereka.

Penelitian oleh Kretchy et al. ${ }^{15}$ mencari tahu hubungan antara hipertensi dengan gejala kecemasan, depresi, dan stress sekaligus mencari tahu pengaruh emosi negatif dalam pengobatan hipertensi. Hasilnya ialah pasien hipertensi memiliki gejala kecemasan, stress, dan depresi. Penelitian ini juga mendapatkan bahwa adanya pengaruh emosi negatif terhadap pengobatan hipertensi. Hasil penelitian oleh Kretchy et al. ${ }^{15}$ tidak sejalan dengan yang didapat pada penelitian ini yaitu bahwa hampir semua responden memiliki afek positif yang dominan.

Hipertensi juga memiliki hubungan erat dengan emosi. Beberapa penelitian telah dilakukan untuk membuktikan kebenaran teori tersebut. McCubbin et al. ${ }^{7}$ 
meneliti perbedaan penurunan emosi pada pasien penyakit kardiovaskular dengan orang aleksitimia untuk lebih memahami peran dari disregulasi afek pada peningkatan tekanan darah. Hasilnya ialah penurunan ekspresi emosi berkontribusi pada disregulasi dan peningkatan risiko penyakit kardiovaskular seperti hipertensi.

\section{Gambaran tingkat kecemasan}

Bachri et al. ${ }^{16}$ menyatakan tingkat kecemasan rata-rata pasien laki-laki lebih rendah dibandingkan tingkat kecemasan pada perempuan. Hal ini sesuai dengan teori yang disampaikan oleh Sunaryo bahwa umumnya seorang laki-laki dewasa mempunyai mental yang kuat terhadap sesuatu yang dianggap mengancam bagi dirinya dibandingkan perempuan. Hasil ini didukung oleh penelitian di RSGMP Kandea Makasar tahun 2014 yang juga menunjukkan hasil dimana laki-laki memiliki tingkat kecemasan yang lebih rendah dibandingkan pada perempuan. Selain itu penelitian yang dilakukan oleh Harfika di Puskesmas Bahu Kecamatan Malalayang Kota Manado tentang gambaran pasien dewasa terhadap tindakan pencabutan gigi juga menunjukkan hasil yang sama bahwa pasien perempuan lebih banyak mengalami kecemasan disbandingkan dengan pasien laki-laki. Hal tersebut dikarenakan secara fisik perempuan lebih lemah dibandingkan laki-laki, dan sifat tersebut membuat perempuan memberikan respon lebih terhadap sesuatu hal yang dianggap berbahaya. ${ }^{17}$ Hasil penelitianpenelitian di atas sesuai dengan hasil penelitian ini yang mendapatkan bahwa tingkat kecemasan rata-rata perempuan lebih tinggi $(87,8 \%)$ dibanding laki-laki $(86,2 \%)$ walaupun perbedaan angkanya tidak begitu besar.

Penelitian oleh Bachri et al. ${ }^{16}$ dan Wiesel et al. ${ }^{18}$ mendukung pernyataan bahwa kecemasan menurun seiring bertambahnya usia. Hal ini kurang sesuai dengan hasil yang didapat pada penelitian di Puskesmas Bahu yaitu tidak terdapat perbedaan nyata antar kelompok usia terhadap tingkat kecemasan.
Al-Saffar dan Saeed ${ }^{19}$ menyatakan terdapat hubungan antara pekerjaan dan kecemasan. Hal ini sesuai dengan hasil penelitian ini yang mendapatkan banyak responden yang menderita kecemasan dibanding yang tidak menderita kecemasan pada semua jenis pekerjaan.

Prasetyorini dan Prawesti ${ }^{10}$ meneliti komplikasi hipertensi, emosi, dan kecemasan menyatakan bahwa banyak hal yang dapat menyebabkan komplikasi hipertensi, salah satunya ialah emosi. Ketika seseorang memiliki afek negatif dalam tubuh maka tubuh akan memroduksi hormon yang dapat meningkatkan tekanan darah. Peningkatan tekanan darah inilah yang memicu terjadinya komplikasi hipertensi. Dampak terjadinya komplikasi hipertensi membuat kualitas hidup penderita menjadi rendah dan kemungkinan terburuknya adalah terjadinya kematian pada penderita akibat komplikasi hipertensi yang dimilikinya. Komplikasi ini kemudian dapat memengaruhi emosi dan menimbulkan kecemasan. Hal tersebut sesuai dengan hasil penelitian ini yaitu sebagian besar responden yang memiliki komplikasi mengalami kecemasan dalam berbagai tingkat. Responden dengan stroke ialah satu-satunya responden dengan komplikasi yang tidak mengalami kecemasan.

Menurut Stuart dan Sundeen, empat level tingkat kecemasan yaitu kecemasan ringan, kecemasan sedang, kecemasan berat, dan kecemasan berat sekali atau panik. ${ }^{20}$ Pada penelitian ini dapat dilihat bahwa kecemasan ringan yang paling banyak dialami pasien hipertensi di Puskesmas Bahu. Hal ini mengindikasikan bahwa sebagian besar pasien hipertensi di Puskesmas Bahu memiliki rasa waspada dan pandangan perseptual yang meningkat. Pandangan perseptual adalah bagaimana pandangan seseorang tentang lingkungan sekitarnya. Mereka menjadi lebih peka dalam menganalisa lingkungan sekitarnya. Selain itu, dapat memotivasi diri untuk belajar dan membuat mereka menjadi dewasa dan kreatif. Hal ini diharapkan memiliki dampak yang baik terhadap keberlangsungan terapi pasien tersebut. 
Rasa waspada dan pandangan perseptual yang meningkat diharapkan membuat pasien menjadi lebih taat untuk rutin minum obat dan menjalani hidup sehat serta menjauhi hal-hal yang dapat memperburuk kondisi tubuh. Hal penting lainnya yang perlu ditekankan adalah bagaimana kecemasan ini tetap berada pada tingkatan ringan dan tidak menjadi kecemasan sedang, berat, atau berat sekali. Perlu adanya dukungan keluarga, orangorang terdekat, dan tenaga kesehatan yang mendampingi. $^{20}$

Kecemasan berat juga banyak ditemukan pada penelitian ini. Hanya selisih 2 orang dengan kecemasan ringan yang berarti masih banyak pasien hipertensi yang mengalami kecemasan berat. Hal ini mengindikasikan bahwa terdapat pengurangan nyata pada pandangan konseptual. Pandangan konseptual adalah cara individu memandang dirinya secara utuh, baik fisikal, emosional, intelektual, sosial dan spiritual. Pasien menjadi fokus pada sumber kecemasan yang dia rasakan dan tidak berpikir lagi tentang hal lain seperti melakukan aktivitas sehari-hari. Semua perilaku yang muncul kemudian bertujuan untuk mengurangi kecemasan. Pasien tidak lagi berfokus untuk rutin minum obat hipertensi dan menjalani pola hidup sehat. Fokusnya yang seharusnya untuk menjaga tekanan darah dan hidup sehat menjadi terganggu. Hal buruk dapat dilakukan pasien seperti minum obat penenang berlebihan hanya untuk mengurangi kecemasan. Perlu adanya pendampingan dari orangorang terdekat serta tenaga medis untuk mengurangi tingkat kecemasan dari pasien ini. Bila perlu, dapat diberikan obat antidepresan, psikoterapi untuk mengurangi kecemasan pada pasien, pantau keadaan pasien, dan terapi simtomatik. ${ }^{20}$

Kecemasan sedang juga banyak ditemukan dan hanya selisih 3 orang dengan kecemasan ringan. Pasien hanya fokus pada urusan yang akan dilakukan dengan segera termasuk mempersempit pandangan perseptual sehingga apa yang dilihat, didengar, dan dirasakan menjadi lebih sempit. Pasien akan fokus pada sumber kecemasan yang dihadapi mulai membuat perencanaan tetapi dia masih dapat melakukan hal lain jika menginginkan untuk melakukan hal lain tersebut. Hal ini berada di antara kecemasan ringan dan berat. Pasien sendiri, orang terdekat, dan tenaga medis harus mulai waspada pada tingkatan ini. Pada tahap ini gejala fisik juga mulai muncul, diberikan obat antidepresan, lakukan psikoterapi untuk mengurangi kecemasan pada pasien, pantau keadaan pasien, dan berikan terapi simtomatik jika diperlukan. Hal ini dilakukan agar tingkat kecemasan menjadi turun dan tidak menjadi kecemasan berat maupun kecemasan berat sekali atau panik. $^{20}$

Tidak ada kecemasan didapatkan pada sejumlah 10 orang $(12,8 \%)$. Hal penting yang perlu ditekankan adalah bagaimana supaya pasien tetap berada pada tingkat kecemasan yang normal. Sebenarnya sesekali merasa cemas bukan menjadi suatu masalah tetapi yang penting ialah bagaimana mengendalikannya.

Kecemasan berat sekali atau panik dialami oleh 4 orang $(5,1 \%)$ pada penelitian ini. Pasien mengalami perasaan ketakutan dan teror luar biasa karena mengalami kehilangan kendali terhadap dirinya. Orang yang mengalami kecemasan berat sekali tidak mampu melakukan sesuatu meskipun diberi pengarahan. Tidak berespon, susah bernapas, halusinasi, dan delusi muncul pada tingkatan ini. Tenaga medis dan orang terdekat dari pasien harus mengambil langkah untuk mengurangi kecemasan dari pasien. Obat anti depresan, terapi simtomatik, psikoterapi, terapi suportif, dan selalu pantau keadaan pasien harus dilakukan. Orang dengan kecemasan berat sekali sangat perlu didampingi. ${ }^{20}$

Data gambaran tingkat kecemasan pada pasien hipertensi di Puskesmas Bahu ini mendukung pernyataan dari beberapa penelitian di bawah ini bahwa ada hubungan antara kecemasan dan hipertensi walaupun hasilnya tidak sama persis.

Penelitian oleh Bajko et al. $^{6}$ yang mencari tahu hubungan antara disfungsi sistem saraf otonom, kecemasan, dan depresi pada pasien hipertensi yang belum 
diobati dan menyatakan bahwa kecemasan berperan penting dalam perkembangan hipertensi. ${ }^{6}$

Pervichko et al. $^{21}$ meneliti tampilan karakteristik dari regulasi emosi pada situasi penuh tekanan yang diperlihatkan oleh pasien dengan hipertensi primer dan menyimpulkan $52,3 \%$ pasien dengan hipertensi memperlihatkan tanda-tanda peningkatan kecemasan disertai dengan beberapa manifestasi.

Harzheim et al. ${ }^{22}$ mengevaluasi prevalensi dari gangguan kecemasan dan depresi dan hubungannya dengan kualitas hidup pada pasien dengan hipertensi pulmonal dan menyimpulkan bahwa kecemasan dan depresi sering didapatkan pada pasien dengan hipertensi pulmonal dan berhubungan dengan kualitas hidup pasien.

Yan et al. ${ }^{23}$ meneliti hubungan antara hipertensi dan kecemasan dan mendapatkan bahwa terdapat hubungan antara kecemasan dengan peningkatan risiko hipertensi. Ilham $^{24}$ meneliti hubungan antara dukungan keluarga dan tingkat kecemasan pada pasien hipertensi di Ruang Rawat Inap RSUD Kota Surakarta dan menyatakan bahwa terdapat hubungan antara dukungan keluarga dengan tingkat kecemasan pada pasien hipertensi di Ruang Rawat Inap RSUD Kota Surakarta. Penelitian ini juga mendapatkan data bahwa mayoritas tingkat kecemasan yang dialami oleh pasien hipertensi di Ruang Rawat Inap RSUD Kota Surakarta ialah kecemasan ringan $(80 \%)$ yang serupa dengan hasil penelitian pada pasien hipertensi di Puskesmas Bahu.

Penelitian oleh Kaldie $^{25}$ mengenai hubungan kecemasan dengan kejadian hipertensi pada lansia di wilayah kerja Puskesmas Poris Plawad Kota Tangerang 2014 melaporkan bahwa terdapat hubungan antara kecemasan dengan kejadian hipertensi pada lansia di wilayah kerja Puskesmas Poris Plawad Kota Tangerang 2014 dengan kecemasan berat menjadi yang terbanyak $(81,1 \%)$.

\section{SIMPULAN}

Dari hasil penelitian ini dapat disimpulkan bahwa sebagian besar pasien dengan hipertensi di Puskesmas Bahu memiliki afek positif yang dominan dan tersering disertai kecemasan ringan.

\section{SARAN}

Untuk masyarakat luas khususnya pasien hipertensi agar lebih sadar akan pentingnya memelihara kesehatan mental.

Untuk instansi kesehatan, berhubung masih banyak pasien khususnya pasien hipertensi yang mengalami kecemasan, perlu memberikan informasi dan edukasi kepada masyarakat tentang pentingnya menjaga kesehatan mental.

Untuk peneliti khususnya yang memfokuskan di bidang kesehatan mental dan hipertensi agar dapat meneliti lebih lanjut tentang kedua hal tersebut karena masih banyak hal yang masih kurang jelas di dalam mekanisme hubungan antara hipertensi dengan keadaan mental.

Penelitian selanjutnya dianjurkan untuk membentuk sebuah tim untuk pengambilan data yang terdiri dari beberapa orang dan terorganisasi dengan baik dan waktu penelitian yang lebih panjang sehingga pengambilan data dapat lebih efisien. Selain itu, dianjurkan juga untuk menyediakan sesuatu yang menarik untuk responden sehingga semua orang yang masuk kriteria inklusi mau berpartisipasi dalam penelitian.

\section{DAFTAR PUSTAKA}

1. Kementerian Kesehatan Republik Indonesia. Rencana Strategis Kementerian Kesehatan Tahun 2015-2019. Kementerian Kesehatan Republik Indonesia. 2015. [cited 2017 Oct 3]. Available from: http://www.depkes.go.id/resources/ download/info-publik/Renstra-2015. pdf.

2. Budijanto D. Hipertensi the Silent Killer. Kementerian Kesehatan Republik Indonesia. 2015. [cited 2017 Aug 23]. Available from: http://www.pusdatin. kemkes.go.id/pdf.php?id=1508030000 1.

3. Dreisbach AW. Epidemiology of Hypertension. Medscape. 2014. [cited 2017 Aug 25]. Available from: http:// emedicine.medscape.com/article/19280 
48-overview\#a3.

4. Pusat Data dan Informasi-Kementerian Kesehatan Republik Indonesia. Hipertensi. Kementerian Kesehatan Republik Indonesia. 2015. [cited 2017 Aug 25]. Available from: http://www.depkes. go.id/download.php?file=download/pus datin/infodatin/infodatin-hipertensi.pdf.

5. Manado Post. Berikut Empat Penyakit Paling Mematikan di Sulut. Manado Post. 2015. [cited 2017 Aug 25]. Available from: http://manadopostonline.com/ ead/2015/03/21/Berikut-Empat-

Penyakit-Paling-Mematikan-di-Sulut/ 8162.

6. Bajko Z, Szekeres CC, Kovacs KR, Csapo K, Molnar S, Soltesz P, et al. Anxiety, depression and autonomic nervous system dysfunction in hypertension. J Neurol Sci. 2012;317(1-2):112-6.

7. McCubbin JA, Loveless JP, Graham JG, Hall GA, Bart RM, Moore DD, et al. Emotional dampening in persons with elevated blood pressure: affect dysregulation and risk for hypertension. Ann Behav Med. 2014;47(1): 111-9.

8. Novitaningtyas T. Hubungan karakteristik (umur, jenis kelamin, tingkat pendidikan) dan aktivitas fisik dengan tekanan darah pada lansia di Kelurahan Makamhaji Kecamatan Kartasura Kabupaten Sukoharjo. Universitas Muhammadiyah Surakarta. 2014. [cited 2017 Dec 16]. Available from: http://eprints.ums.ac.id/29084/9/02._Na skah_Publikasi.pdf

9. Basofi DA. Hubungan Jenis kelamin, pekerjaan dan status pernikahan dengan tingkat kecemasan pada pasien operasi katarak di Rumah Sakit Yarsi Pontianak. Universitas Tanjungpura Pontianak. 2016. [cited 2017 Dec 16]. Available from: http://jurnal.untan. ac.id/index.php/jfk/article/view/18114/ 15326.

10. Prasetyorini HT, Prawesti D. Stres pada penyakit terhadap kejadian komplikasi hipertensi pada pasien hipertensi. Jurnal STIKES. 2012;5(1):61-70.

11. Andrea GY. Korelasi derajat hipertensi dengan stadium penyakit ginjal kronik di RSUP Dr. Kariadi Semarang Periode 2008-2012. Universitas Diponegoro. 2013. [cited 2017 Dec 16]. Available from: http://eprints.undip.ac.id/ 43896/3/Gilang_YA_G2A009181_Bab 2KTI.pdf.

12. Ratnasari S, Suleeman J. Perbedaan regulasi emosi perempuan dan laki-laki di perguruan tinggi. Jurnal Psikologi Sosial. 2017;15(1):35-46.

13. Shallcross JA, Ford BQ, Floerke VA, Mauss BI. Getting better with age: The relationship between age, acceptance, and negative affect. J Pers Soc Psychol. 2013;104(4):734-749.

14. CareerCast.com. Most Stressful Jobs 2017. CareerCast.com. 2017. [cited 2017 Dec 16]. Available from: http://www. careercast.com/jobs-rated/moststressful-jobs-2017.

15. Kretchy IA, Owusu-Daaku FT, Danquah SA. Mental health in hypertension: assessing symptoms of anxiety, depression, and stress on antihypertensive medication adherence. Int J Ment Health Syst. 2014;8:25.

16. Bachri S, Cholid Z, Rochim A. Perbedaan tingkat kecemasan pasien berdasarkan usia, jenis kelamin, tingkat pendidikan dan pengalaman pencabutan Gigi di RSGM FKG Universitas Jember. eJurnal Pustaka Kesehatan. 2017;5(1): 138-144.

17. Pramanto R, Munayang H, Hutagalung BSP. Gambaran tingkat kecemasan terhadap tindakan pencabutan gigi anak kelas 5 di SD Katolik Frater Don Bosco Manado. Jurnal Ilmiah FarmasiUNSRAT. 2017;6(4):201-5.

18. Weiss WTR, Nelson CJ, Tew WP, Hardt M, Mohile SG, Owusu C, et al. The relationship between age, anxiety, and depression in older adults with cancer. Psychooncology. 2015;24(6):712-7.

19. Al-Saffar NM, Saeed DA. Generalized anxiety disorder in type 2 diabetes mellitus in Suleimaniya city. Tikrit Med J. 2009;15(1):78-85.

20. Eka AR. Hubungan Tingkat kecemasan dengan keberhasilan memberikan obat melalui infus pada mahasiswa FIK UI Angkatan 2010. Universitas Indonesia. 2012. [cited 2017 Sep 5]. Available from: http://lontar.ui.ac.id/file?file= digital/20301345-S42018-Angelina\% 20Roida\%20Eka.pdf.

21. Pervichko E, Zinchenko Y, Ostroumova O. Emotion regulation in patients with 
essential hypertension: subjectiveevaluative, physiological, and behaveoral aspects. Procedia - Social and Behavioral Sciences. 2014;127:686-90.

22. Harzheim D, Klose H, Pinado FP, Ehlken N, Nagel C, Fischer C, et al. Anxiety and depression disorders in patients with pulmonary arterial hypertension and chronic thromboembolic pulmonary hypertension. Respir Res. 2013;14:104.

23. Pan Y, Cai W, Cheng Q, Dong W, An T, Yan J. Association between anxiety and hypertension: A systematic review and meta-analysis of epidemiological studies. Neuropsychiatr Dis Treat. 2015;11:1121-30.

24. Ilham M. Hubungan antara dukungan keluarga dengan tingkat kecemasan pada pasien hipertensi di Ruang Rawat Inap RSUD Kota Surakarta. Sekolah Tinggi Ilmu Kesehatan Kusuma Husada Surakarta. 2016. [cited 2017 Nov 22]. Available from: http:// digilib.stikeskusumahusada.ac.id/files/d isk1/29/01-gdl-muhammadil-1444-1muhammad-_.pdf.

25. Kaldie. Hubungan kecemasan dengan kejadian hipertensi pada lansia di wilayah kerja Puskesmas Poris Plawad Kota Tangerang 2014. Universitas Esa Unggul. 2014. [cited 2017 Nov 22]. Available from: http://digilib. esaunggul.ac.id/public/UEUUndergraduate-2398Cover\%20Skripsi.pdf. 